\title{
RNA:DNA ratios as indicators of nutritional condition in the copepod Calanus finmarchicus
}

\author{
M. Wagner ${ }^{1, *}$, E. Durbin ${ }^{1}$, L. Buckley ${ }^{2}$ \\ ${ }^{1}$ Graduate School of Oceanography, University of Rhode Island, Narragansett, Rhode Island 02882, USA \\ ${ }^{2}$ URI-NOAA CMER Program, Graduate School of Oceanography, University of Rhode Island, Narragansett, \\ Rhode Island 02882, USA
}

\begin{abstract}
As part of an investigation of ribonucleic acid (RNA) content as an index of growth and nutritional condition of zooplankton in the field, we describe here a method for measuring RNA and DNA in individuals, Stage N5 through adult, of the copepod Calanus finmarchicus. We used the technique to compare total RNA and DNA content and RNA:DNA ratios of $C$. finmarchicus copepodite stages cultured at different food densities. Copepods reared at growth-limiting phytoplankton concentrations (25 $\mathrm{\mu g}$ carbon $\mathrm{l}^{-1}$ ) were smaller, had lower RNA:DNA ratios, and contained less total RNA and DNA than did copepods reared in excess food $\left(500 \mathrm{\mu g} \mathrm{C} \mathrm{l}^{-1}\right)$. This was true for each stage from $\mathrm{C} 1$ to C5. Stages C5 and C4 C. finmarchicus collected from Georges Bank and the Gulf of Maine were compared to those from the laboratory experiment. While RNA:DNA ratios of C5 and C4 individuals collected in May and June 1994 were intermediate between the 2 lab treatments, Stage C5 C. finmarchicus collected in November 1993 had the lowest RNA:DNA ratios of all copepods sampled. This seasonality of RNA:DNA ratios is most likely related to food availability and changing metabolic activity. Our data show that RNA is a useful index of physiological condition for $C$. finmarchicus.
\end{abstract}

KEY WORDS: Copepods · Calanus finmarchicus - RNA:DNA ratios · Nutrition - Growth

\section{INTRODUCTION}

Measurement of zooplankton growth rates and assessment of their nutritional state are important in studies of secondary production. Zooplankton growth in the field is commonly estimated by incubating animals in ambient seawater and determining the increase of carbon or dry weight during the incubation period (Kimmerer \& MacKinnon 1987). Other methods have used molting rates (Heinle 1966, Miller et al. 1984, Runge et al. 1985) or egg production (Checkley 1980, Durbin et al. 1983, Runge 1985) as indices of growth rate. Biochemical growth-rate indicators, such as RNA concentration or the RNA:DNA ratio, are routinely used for estimating growth rates and nutritional condition of larval fish in the field (Buckley 1984, Clemmesen 1988); however, only a few studies have applied these techniques to zooplankton. These stud-

•E-mail: mwagner@gsosun1.gso.uri.edu ies have produced mixed results regarding the use of RNA as a growth-rate index.

The RNA content of several species of copepods and euphausiids reflects the seasonal pattern in food supply and reproductive activity (Båmstedt 1983, Nakata et al. 1994). A number of researchers have reported a correlation of RNA concentration with growth rate in copepods and other zooplankton. Some have attempted to formulate a general relationship which applies to most invertebrate zooplankton (Sutcliffe 1965, 1969, Båmstedt \& Skjoldal 1976, 1980, Skjoldal \& Båmstedt 1976), but others have found that the relationship is only valid under certain temperature and food conditions (Ota \& Landry 1984), or during certain stages of the life history (Dagg \& Littlepage 1972).

Because RNA is an essential component of protein synthesis, its concentration in tissue often reflects the rate of protein synthesis. The RNA:DNA ratio provides an index of protein synthetic capacity per cell since the amount of DNA per cell is assumed not to vary with 
condition or with growth rate (Bulow 1987). The RNA content of tissue is related to growth rate, food density, and temperature and may also be affected by gamete production and developmental stage

This study is the beginning of a project examining the relationship of RNA content, temperature, and growth rate for Calanus finmarchicus, a dominant copepod of the Gulf of Maine and Georges Bank region of the Northwest Atlantic. The first step in this project was to evaluate how food availability affects nucleic acid levels in this species. We examined the variation in total RNA, total DNA, and the RNA:DNA ratio during copepodite Stages $\mathrm{C} 1$ through $\mathrm{C} 5$ in $\mathrm{C}$. finmarchicus reared at 2 different food concentrations. In order to measure RNA and DNA of very small individual copepods, we adapted the fluorometric assay of Bentle et al. (1981) to a 96-well microplate format. The resulting technique, the microplate fluorescent assay (MFA), is similar to that of Nacci et al. (1994), who first used a microplatebased RNA-DNA assay with marine animals. Our MFA is capable of measuring nucleic acids in individual copepodite stages and late naupliar stages of $C$. finmarchicus. Copepod samples from the laboratory experiment were used to intercalibrate the MFA with another fluorometric RNA-DNA assay, the flow-injection analysis (FIA) technique of Caldarone \& Buckley (1991). Copepods collected in the field in 1993 and 1994 were analyzed by the FIA method and their mean RNA:DNA ratios were converted in order to be qualitatively compared with the laboratory experiment.

\section{METHODS}

Measuring RNA and DNA: the microplate fluorescent assay. Nucleic acids from laboratory-grown Calanus finmarchicus were measured by using a modification of the Bentle et al. (1981) DNA and RNA assay. This is an ethidium bromide fluorometric tech.nique in which RNA, then DNA, are sequentially degraded with nucleases (RNase and DNase). The concentration of each nucleic acid is determined from the difference in fluorescence measurements taken before and after each enzyme treatment. We found that for C. finmarchicus, the DNase step could be eliminated, nearly doubling the number of samples which could be analyzed in $1 \mathrm{~d}$. Adapting the technique to 96-well microplates enabled us to measure the small quantities of DNA and RNA found in individual copepodites and late naupliar stages of $C$. finmarchicus (detection limit $15 \mathrm{ng}$ DNA or RNA per well). The modified Bentle et al. (1981) assay, when combined with the sarcosyl extraction technique described by Caldarone \& Buckley (1991), allows 1 person to process up to 140 samples per 8 -hour day.
Working reagents: Tris buffer: $10 \mathrm{mM}$ Tris, $1 \mathrm{mM}$ $\mathrm{Na}_{2}$ EDTA, pH 7.5. Extraction buffer: $1 \% \mathrm{~N}$-lauroylsarcosine (sarcosyl) in Tris buffer (Sigma, catalog no. L5125). Standard buffer: $0.2 \%$ sarcosyl in Tris buffer. Ethidium bromide (EB) solution: $2.0 \mu \mathrm{g} \mathrm{ml}^{-1}$ in Tris buffer (Gene-Mater. catalog no. 5515-10). Ribonuclease A (RNase): 50 Kunitz $\mathrm{U} \mathrm{ml}^{-1}$ in Tris buffer (Sigma catalog no. R-6513).

Standards and controls: Standard DNA (calf-thymus, Hoefer Scientific TKO-102) and RNA (eukaryotic $18 \mathrm{~S}$ and $28 \mathrm{~S}$ ribosomal RNA, Sigma R-0889) stocks were diluted with Tris buffer to approximately $40 \mu \mathrm{g}$ $\mathrm{ml}^{-1}$. Exact concentrations of the stock solutions were determined spectrophotometrically, and they were aliquotted and stored at $-80^{\circ} \mathrm{C}$. Working DNA and RNA preparations were diluted in Standard buffer. Working DNA standards ranged from $0.200 \mu \mathrm{g} \mathrm{ml}^{-1}$ to $2.00 \mathrm{Hg} \mathrm{ml}^{-1}$. Standard RNA concentrations ranged from $0.200 \mu \mathrm{g} \mathrm{ml}^{-1}$ to $8.00 \mu \mathrm{g} \mathrm{ml}^{-1}$. A C. finmarchicus control homogenate was prepared by grinding $0.69 \mathrm{~g}$ (wet weight) of adult copepods in a glass homogenizer with $1.00 \mathrm{ml}$ of distilled, deionized water. The homogenate was stored in $5 \mu \mathrm{l}$ aliquots at $-80^{\circ} \mathrm{C}$. Each day, an aliquot of the control homogenate was extracted and analyzed along with the copepod samples.

Protocol: The copepod samples were extracted by a modification of the sarcosyl extraction technique described by Caidarone \& Buckley (1991). The samples were homogenized by vigorous shaking with an appropriate volume of $1 \%$ sarcosyl Extraction buffer. The volume of Extraction buffer varied with stage according to Table 1 . Samples were shaken for $1 \mathrm{~h}$ at room temperature on a vortex mixer equipped with a multiple-vial head. They were then diluted 1:4 with Tris buffer (volumes given in Table 1 ) to reduce the sarcosyl concentration to $0.2 \%$. The samples were shaken again for $5 \mathrm{~min}$, then centrifuged $(12000 \times \mathrm{g})$ for 10 min to sediment any insoluble copepod remains. The control homogenate was extracted in $200 \mu \mathrm{l}$ of Extraction buffer and was treated as previously described for copepod samples.

Duplicate $75 \mu \mathrm{l}$ aliquots of controls, unknowns, and working standards were transferred to 96-well microtiter plates (Falcon Pro-bind). Controls were included on each plate so that we could monitor variation between plates. Seventy-five microliters of ethidium bromide (EB) solution was added to each well. The plates were shaken gently at room temperature for 15 min then scanned on a BioTek FL-500 fluorescence plate reader with $530 \mathrm{~nm}$ (excitation) and $590 \mathrm{~nm}$ (emission) filters. We set the plate reader options so that the probe would stop on each well for $0.1 \mathrm{~s}$ and take 10 replicate measurements, presenting the average of the 10 as the fluorescence measurement for the well. 
Table 1. Extraction and dilution protocol for the microplate fluorescent assay (MFA). Individual copepods of a given stage are extracted in the specified volume of Extraction buffer then diluted 1:4 with Tris buffer to yield the final volume given below

\begin{tabular}{|cccc|}
\hline Stage & $\begin{array}{c}\text { Extraction } \\
\text { buffer }(\mu \mathrm{l})\end{array}$ & $\begin{array}{c}\text { Tris } \\
\text { buffer }(\mu \mathrm{l})\end{array}$ & $\begin{array}{c}\text { Final } \\
\text { volume }(\mu \mathrm{l})\end{array}$ \\
\hline $\mathrm{C} 1$ & 75 & 300 & 375 \\
$\mathrm{C} 2$ & 100 & 400 & 500 \\
$\mathrm{C} 3$ & 150 & 600 & 750 \\
$\mathrm{C} 4$ & 200 & 800 & 1000 \\
C5 & 300 & 1200 & 1500 \\
C6 & 300 & 1200 & 1500 \\
\hline
\end{tabular}

Following the first scan, $7.5 \mu$ of RNase solution was added to each well, including all standards. The plate was shaken again at room temperature for $20 \mathrm{~min}$ and scanned a second time. RNA concentrations were calculated from the difference in fluorescence between the first and second scans and DNA concentrations were calculated from the fluorescence of the second scan (Fig. 1). Standard curves were plotted by using the average fluorescence of the duplicate wells for each concentration. DNA standard values were 0.0150 , $0.0450,0.0750,0.105$, and $0.150 \mu \mathrm{g} \mathrm{well}^{-1}$; RNA standard values were $0.0150,0.0750,0.150,0.300,0.450$, and $0.600 \mu \mathrm{g} \mathrm{well}^{-1}$. Unknown values were converted from $\mu \mathrm{g}$ well ${ }^{-1}$ to $\mu \mathrm{g}$ ind.$^{-1}$ by the calculation

$$
\frac{\mu \mathrm{g} \text { nucleic acid }}{\text { copepod }}=\frac{\mu \mathrm{g} \text { nucleic acid }}{\text { well }} \times \frac{\text { final volume in } \mu \mathrm{l}}{75.0 \mu \mathrm{l}}
$$

where the final volume for each stage is that given in Table 1.

Laboratory experiment. Culturing Calanus finmarchicus: Copepods were reared in the laboratory from eggs produced by adult female $C$. finmarchicus collected in the Gulf of Maine. Zooplankton were callected near Portsmouth, New Hampshire, USA, in March 1994. Several hundred adult females were isolated and were placed in $20 \mathrm{l}$ polycarbonate buckets at a density of 10 ind. $\mathrm{l}^{-1}$. They were fed a mixture of cultured phytoplankton (Prorocentrum micans, Gymnodinium sanguineum, Heterocapsa triquetra, and Tetraselmis sp.). To start the experimental cultures, 180 females were placed in a $200 \mu \mathrm{m}$ mesh inside a 201 polycarbonate bucket containing $0.45 \mu \mathrm{m}$ filtered seawater (FSW). Eggs were collected for $24 \mathrm{~h}$, then the mesh containing the female $C$. finmarchicus was moved to a new container with fresh FSW and phytoplankton. Four batches, each containing about 4000 eggs, were collected on 4 consecutive days and were designated Tanks 1, 2, 3, and 4. Tanks 1 and 3 were assigned to the high-food treatment, and Tanks 2 and 4 to the low-food treatment. Immediately after collec-

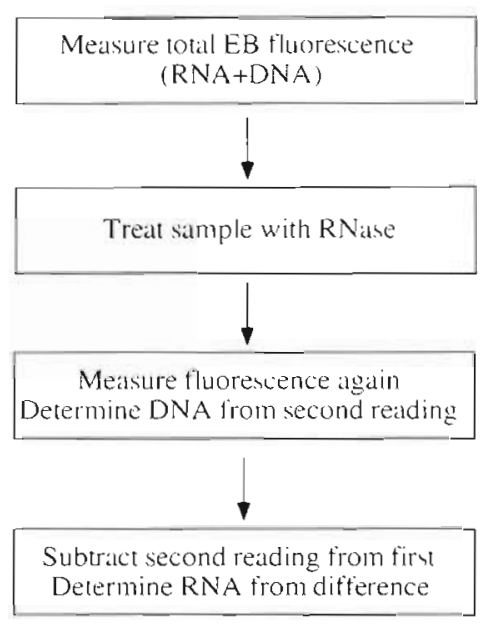

Fig. 1. Steps in the microplate fluorescent assay (MFA)

tion, each batch of eggs was placed in a cylindrical polyethylene tank (capacity 55 l) containing a total of $20 \mathrm{l}$ of filtered seawater. The tanks were maintained at $12 \pm 1^{\circ} \mathrm{C}$ on a $12 \mathrm{~h}$ light: $12 \mathrm{~h}$ dark light cycle and were gently aerated. The density of the copepod cultures was initially 200 nauplii $\mathrm{l}^{-1}$, and the cultures were diluted as the animals developed to a final density of less than 10 ind. $\mathrm{l}^{-1}$ at stage $\mathrm{C} 5$.

Starting at the third naupliar stage, the copepods were fed cultured phytoplankton at excess or growthlimiting cell densities. Tanks in the high-food treatment were fed the equivalent of $500 \mu \mathrm{g} \mathrm{Cl}^{-1}$; tanks in the low-food treatment were fed $25 \mu \mathrm{g} \mathrm{C} \mathrm{l}^{-1}$. Naupliar stages were fed a mixture of equal parts Gymnodinium sanguineum, Heterocapsa triquetra, and Tetraselmis $\mathrm{sp}$. Copepodite stages were fed a mixture of 2 parts $G$. sanguineum and 1 part $H$. triquetra. Tetraselmis sp. was eliminated from the diet since the copepodites preferred the larger dinoflagellates. Phytoplankton were grown in the same temperature and light conditions as the copepods. Phytoplankton densities in the tanks were adjusted once daily, about $2 \mathrm{~h}$ before dark. In the high food treatment, food densities remained at 50 to $75 \%$ of the nominal density after $24 \mathrm{~h}$; in the low food treatment, all food was grazed within $24 \mathrm{~h}$.

Sampling: Cultures of Calanus finmarchicus were sampled throughout the life cycle, but only copepodite stages and adults will be discussed here. Although the sex ratio of the adults was approximately 1 male to 3 females, only females were sampled for RNA and DNA analyses. Males were not sampled because we felt that they were more valuable if kept alive for breeding. The copepod cultures were sampled at intervals of 2 or more days, depending on their development rate; we attempted to sample at least twice during each stage. The high-food tanks were sampled at 2 or 3 intervals throughout the experiment. Because 
the food-limited copepods developed more slowly with time, the sampling interval of the low-food tanks was increased to $3,4,5$, then finally to $6 \mathrm{~d}$. The cultures were sampled at the same time each day, about $3 \mathrm{~h}$ after the lights came on. At each sampling, a volume estimated to contain at least 25 ind. was removed from each culture. The animals were anesthetized with MS-222 (tricaine methane sulfonate; $0.576 \mathrm{~g} \mathrm{l}^{-1}$ ) and kept in a petri dish on ice during all subsequent sampling steps.

Twenty-five individual copepods were chosen at random. For each copepod sampled, developmental stage was noted and a video image was recorded for later length measurement. Copepods were placed individually in $1.5 \mathrm{ml}$ microcentrifuge tubes, and stored at $-80^{\circ} \mathrm{C}$. Prosome lengths for each copepod were determined from the video images by using NIH Image 1.47 image-analysis software. About one-half of the samples were analyzed by the MFA technique described in this paper, the other half were analyzed by a modification of the flow-injection analysis (FIA) technique described by Caldarone \& Buckley (1991). The mean RNA:DNA ratios from each stage within each treatment, determined from data collected by both assays, were used to intercalibrate the 2 techniques so that laboratory data generated by the MFA technique could be compared to field data generated by the FIA method.

To check for effects of ingested food on RNA:DNA ratios, we placed 30 well-fed Stage C3 copepodites into filtered seawater for $48 \mathrm{~h}$ without food. Thirty animals were kept in excess food. Ten individuals from each treatment were sampled at 0,24 , and 48 h. After $24 \mathrm{~h}$, there was no food visible in the guts of the starved animals. RNA:DNA ratios of the starved group averaged 2.444 (SD 0.108) compared to $2.889 \pm 0.161$ for the controls. Although a $12 \mathrm{~h}$ incubation might have been more appropriate, it is clear that the decline over $24 \mathrm{~h}$ was too small for ingested food to account for the large treatment differences observed in the experiment.

Statistics: All statistical comparisons were done by SAS v 6.0 run on an IBM-compatible personal computer. Since sample sizes varied, analysis of variance was done by using the SAS procedure PROC GLM.

Sampling Calanus finmarchicus in the field. In order to compare the lab cultures with wild specimens, we collected $C$. finmarchicus in the field on 2 occasions at different phases of the life cycle. Stage C5 Calanus were collected in the Gulf of Maine (Wilkinson Basin and Jordan Basin) in November
1993, and Stages C4 and C5 individuals were collected in late May and early June 1994 in the Gulf of Maine (Georges Basin) and Georges Bank. Zooplankton were collected by vertical tows with a $1 \mathrm{~m}^{2}$ ring net $(153 \mu \mathrm{m}$ or $333 \mu \mathrm{m}$ mesh size). Depths of tows varied with water depth and the location of C. finmarchicus within the water column. Once aboard ship, the zooplankton were anesthetized with MS-222 and sorted. C5 and C4 C. finmarchicus were placed individually in $1.7 \mathrm{ml}$ cryovials and were stored over liquid nitrogen. Upon arrival at the lab, they were stored at $-80^{\circ} \mathrm{C}$. RNA and DNA in the field-collected copepod samples were measured by the FIA technique of Caldarone \& Buckley (1991). This method was found to be unsuitable for nauplii and early copepodite stages with low total RNA content and low RNA:DNA ratios, but worked well for the C4 and C5 animals in this study. Length measurements were not taken for the field-collected copepods.

\section{RESULTS}

\section{Analytical results}

Linearity of standards was excellent. $\mathrm{R}^{2}$ values typically exceeded 0.9950 and often exceeded 0.9990 (Fig. 2). Well-to-well reproducibility was good, coefficients of variation for 6 replicate wells of 3 different samples averaged $3.15 \%$ for DNA and $4.22 \%$ for RNA. Plate-to-plate and day-to-day variability was reasonably low, coefficients of variation of the control homogenate were $6.50 \%$ for DNA and $6.45 \%$ for RNA over 5 mo (49 plates). Known amounts of DNA and RNA (spikes) were added to some of the samples and controls. Eight DNA spikes of $0.500 \mu \mathrm{g} \mathrm{ml}^{-1}$ averaged $97.0 \%$ recovery (range 85 to $109 \%$ ) and 12 RNA spikes of $0.200,0.500$, or $1.00 \mu \mathrm{g} \mathrm{m} \mathrm{m}^{-1}$ averaged $92 \%$ (range 76 to $118 \%$ ). Endogenous fluorescence of copepod extracts was measured by replacing the ethidium bro-
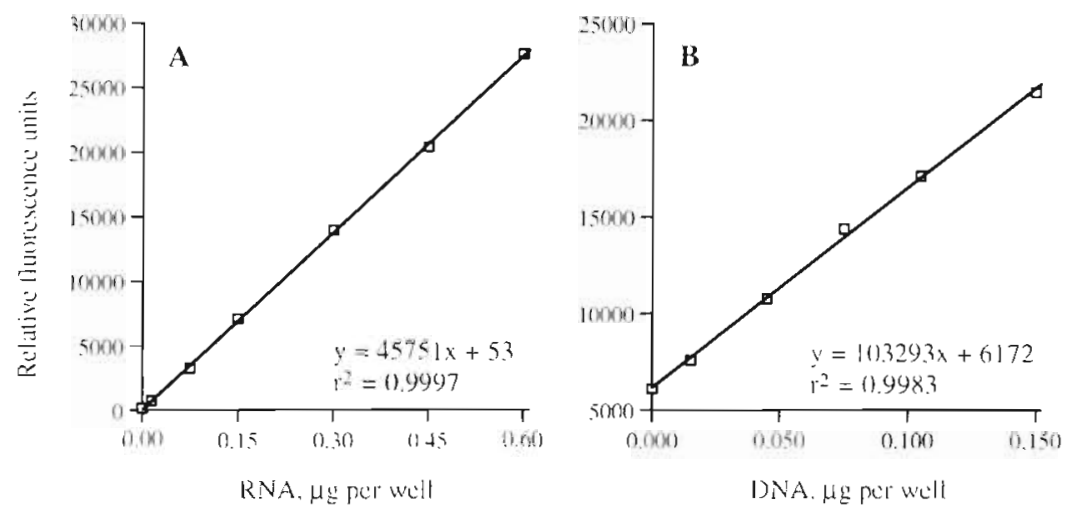

Fig. 2. Standard curves generated by the MFA for (A) RNA and (B) DNA 
mide solution with Tris buffer and scanning the plate at the usual excitation and emission wavelengths. No endogenous fluorescence was detected in Calanus finmarchicus at any stage of development. Residual fluorescence, the fluorescence left over when samples were treated with both RNase and DNase, averaged $8 \%$ of the total original fluorescence. As a compromise between accuracy and efficiency, we chose to eliminate the DNase step. Because DNase requires a longer incubation at elevated temperatures, eliminating this step of the procedure nearly doubled the number of samples that could be analyzed in $1 \mathrm{~d}$. It should be recognized that the small residual fluorescence is included in DNA concentrations calculated in this manner.

\section{Effect of food level on development rate, body size, and nucleic acids}

The well-fed copepods in the laboratory experiment matured and produced viable eggs, but the experiment was terminated before adults had appeared in the low-food treatment. Data were grouped by stage regardless of when they were collected, so that each 'stage' class was made up of individuals collected on more than $1 \mathrm{~d}$. Data are presented for stages C1 through $\mathrm{C} 5$ in the low-food treatment, and for $\mathrm{C} 1$ through adult females in the high-food treatment. The food-limited copepods developed more slowly than the well-fed copepods, taking about $47 \mathrm{~d}$ for $50 \%$ of the animals to reach stage $\mathrm{C} 5$, compared to $23 \mathrm{~d}$ for the well-fed copepods.

Animals in the low-food treatment were smaller at every stage studied, as is shown by their lengths and total DNA contents. The mean prosome length of copepods in the low food treatment increased from $0.65 \mathrm{~mm}$ at Stage C1 to $1.75 \mathrm{~mm}$ at Stage C5, while the range for the high-food treatment over the same stages was from $0.90 \mathrm{~mm}$ to $2.14 \mathrm{~mm}$ (Fig. 3A). Total DNA was also different in the 2 treatments, increasing from 0.25 to $0.69 \mathrm{~kg}$ ind $^{-1}$ in the low food treatment and from 0.30 to $1.03 \mu \mathrm{g}$ ind.$^{-1}$ in the high food treatment (Fig. 3B)

Food limitation clearly affected the RNA content and RNA:DNA ratios of copepods in this experiment. Total RNA ranged from $0.11 \mu \mathrm{g}$ ind.$^{-1}$ for $\mathrm{C} 1$ to $1.05 \mu \mathrm{g}$ for $\mathrm{C} 5$
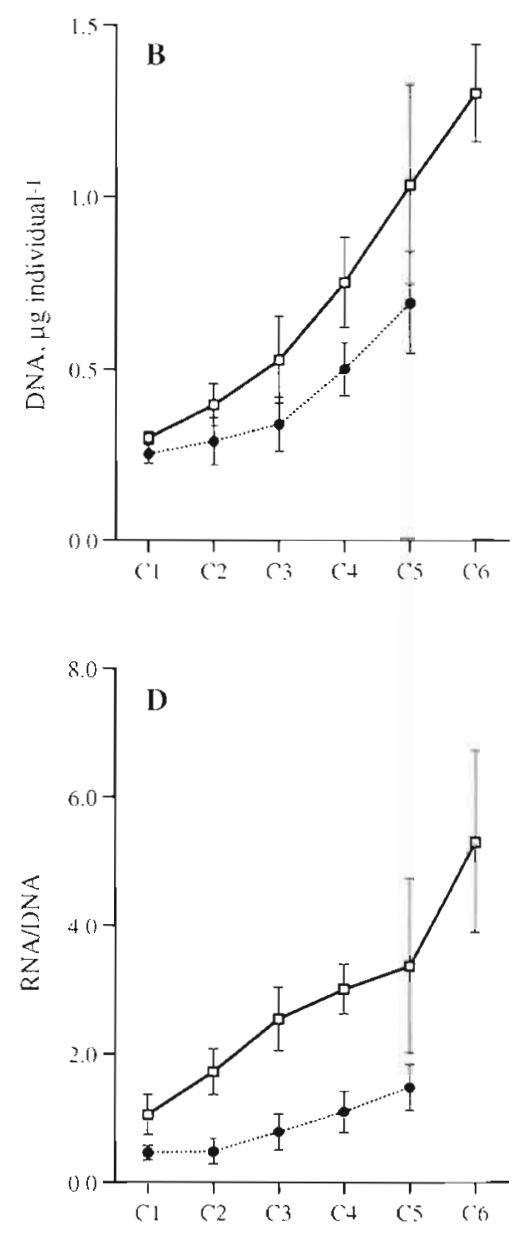

Fig. 3. Calanus finmarchicus. (A) Prosome length, and (B) total DNA, (C) total RNA, and (D) RNA:DNA of copepodite stages cultured at $12^{\circ} \mathrm{C}$ in phytoplankton concentrations equivalent to 500 (high food) and 25 (low food) $\mu \mathrm{g} \mathrm{Cl} \mathrm{Cl}^{-1}$ Error bars show $\pm 1 \mathrm{SD}$. At each stage, prosome length, total DNA, total RNA, and RNA:DNA were significantly different between food treatments (2-way ANOVA, $\mathrm{p}<0.05$, and $t$-tests, $\mathrm{p}<0.01)$

in the low-food treatment, and from 0.32 to $3.19 \mu \mathrm{g}$ in the high-food treatment (Fig. 3C). The difference in total RNA content cannot be accounted for solely by differences in body size, since the mean RNA:DNA ratios for each stage also differed among the treatments (Fig. 3D). RNA:DNA ratios increased from 0.46 to 1.48 in the low food treatment and from 1.05 to 3.37 in the high food treatment.

The effects of food treatments, developmental stage, and replicate tanks were compared for each of the 4 dependent variables length, total DNA, total RNA, and RNA:DNA by using 2-way ANOVA (Food $\times$ Stage with a third independent variable, Tank, nested within Food). Outcomes of the 4 analyses are presented in Table 2 . The effects of food and stage were significant $(p<0.05)$ for each of the dependent variables. Significant differences between replicate tanks were found only for the dependent variable length. A significant 
Table 2. Two-way nested ANOVA for effects of food level, replicate tank, and stage for each of the dependent variables prosome length, total IDNA, total RNA and RNA:DNA. Calanus finmarchicus were reared through stages C1 to C5 at 2 food densities Sigmificant effects were found for both food and stage for all variables. Only the variable length showed a significant tank effect. Significant food $\times$ stage interactions were found for total DNA, total RNA, and RNA:DNA and significant tank $\times$ stage interactions were found for all variables

\begin{tabular}{|c|c|c|c|c|c|c|}
\hline Variable & Source & $\mathrm{df}$ & SS & MS & $F$ & $\mathrm{p}$ \\
\hline \multirow[t]{6}{*}{ Length } & Food & 1 & 3.238 & 3.238 & 80.41 & 0.0001 \\
\hline & Stage & 5 & 21.666 & 4.333 & 107.62 & 0.0001 \\
\hline & Tank (Food) & 2 & 0.254 & 0.127 & 3.15 & 0.0445 \\
\hline & Tank $\times$ Stage (Food) & 8 & 0.652 & 0.081 & 2.02 & 0.0447 \\
\hline & Food $\times$ Stage & 4 & 0.276 & 0.069 & 1.71 & 0.1478 \\
\hline & Error & 227 & 9.140 & 0.040 & & \\
\hline \multirow[t]{6}{*}{ Total DNA } & Food & 1 & 1.094 & 1.094 & 77.81 & 0.0001 \\
\hline & Stage & 5 & 5.083 & 1.017 & 72.30 & 0.0001 \\
\hline & Tank (Food) & 2 & 0.038 & 0.019 & 1.34 & 0.2650 \\
\hline & Tank $\times$ Stage $($ Food $)$ & 8 & 0.588 & 0.073 & 5.22 & 0.0001 \\
\hline & Food $\times$ Stage & 4 & 0.302 & 0.075 & 5.36 & 0.0004 \\
\hline & Error & 227 & 3.1 .92 & 0.014 & & \\
\hline \multirow{6}{*}{ Total RNA } & Food & 1 & 41.929 & 41.929 & 269.30 & 0.0001 \\
\hline & Stage & 5 & 108.627 & 21.725 & 139.54 & 0.0001 \\
\hline & Tank (Food) & 2 & 0.605 & 0.303 & 1.94 & 0.1455 \\
\hline & Tank $\times$ Stage (Food) & 8 & 3.334 & 0.417 & 2.68 & 0.0079 \\
\hline & Food $\times$ Stage & 4 & 17.466 & 4.367 & 28.05 & 0.0001 \\
\hline & Error & 227 & 35.343 & 0.156 & & \\
\hline \multirow[t]{6}{*}{ RNA:DNA } & Food & 1 & 70.589 & 70.589 & 298.24 & 0.0001 \\
\hline & Stage & 5 & 63.293 & 12.659 & 53.48 & 0.0001 \\
\hline & Tank (Food) & 2 & 0.867 & 0.433 & 1.83 & 0.1626 \\
\hline & Tank $\times$ Stage $($ Food $)$ & 8 & 16.390 & 2.049 & 8.66 & 0,0001 \\
\hline & Food $\times$ Stage & 4 & 8.579 & 2.145 & 9.06 & 0.0001 \\
\hline & Error & 227 & 53.728 & 0.237 & & \\
\hline
\end{tabular}

interaction of tank and stage for all 4 independent variables indicated that within each food-stage combination the replicate tanks sometimes differed even though there was not always an overall tank effect. The interaction of food and stage was significant for total DNA, total RNA, and RNA:DNA. Since for these variables there was a significant food-stage interaction, but no overall effect of replicate tanks, we examined the effect of food at each stage by using a series of $t$-tests; data from the 2 tanks at each food level were pooled. A significant effect of food level was found at each stage for each of the variables length, total DNA, total RNA, and RNA:DNA $(p<0.01)$.

\section{RNA:DNA ratios of field-collected copepods}

In order to compare field data generated by the FIA technique with laboratory data generated by the MFA, RNA:DNA ratios from the field samples analyzed by the FIA method were converted to predicted values for the microplate fluorometric assay. To calibrate the 2 methods, linear regression was performed on the mean values for each stage within each treatment (Table 3 ).
Means were used for calibration because different individual samples from the same cultures were ana-

Table 3. Comparison of RNA:DNA ratios from the flow-injection analysis (FlA) method of Caldarone \& Buckley (1991) with ratios from the MFA. Mean RNA:DNA ratios were used for each developmental stage in each food treatment because different sets of samples were analyzed by the 2 assays. Values in parentheses show sample sizes for each stage-food combination. RNA:DNA $A_{\text {MFA }}=1.333$ RNA:DNA FiA $_{-0.0733}-r^{2}=0.981$

\begin{tabular}{|lll|}
\hline Stage & RNA:DNA & \\
\hline Low food & RNA:DNA $_{\text {MFA }}$ \\
C1 & & \\
C2 & $0.252(14)$ & $0.459(42)$ \\
C3 & $0.324(40)$ & $0.478(89)$ \\
C4 & $0.537(46)$ & $0.783(90)$ \\
C5 & $0.928(27)$ & $1.097(64)$ \\
High food & $1.304(7)$ & $1.479(25)$ \\
C1 & & $1.054(2)$ \\
C2 & $1.217(5)$ & $1.723(11)$ \\
C3 & $1.388(27)$ & $2.543(34)$ \\
C4 & $1.856(22)$ & $3.005(59)$ \\
C5 & $2.347(32)$ & $3.367(83)$ \\
C6 & $2.417(26)$ & $5.33(12)$ \\
\hline
\end{tabular}




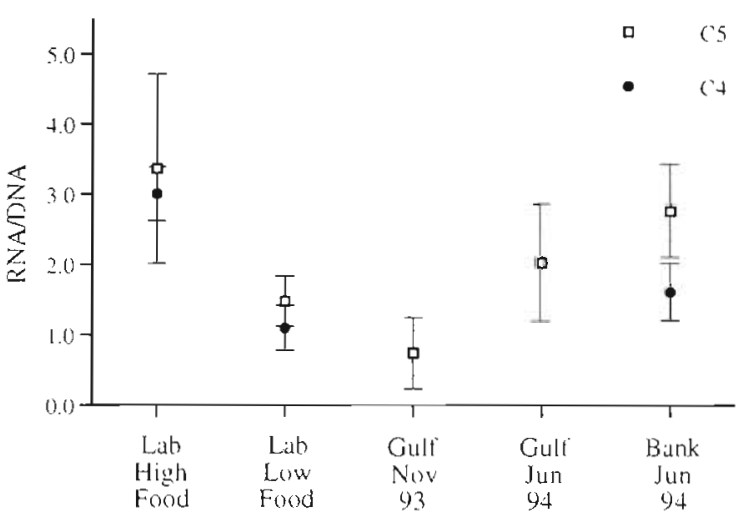

Fig. 4. Comparison of field-caught Calanus finmarchicus with copepods reared in the laboratory at $12^{\circ} \mathrm{C}$. C5 individuals were collected from the Gulf of Maine in November 1993, Gulf of Maine in June 1994 and Georges Bank in June 1994. C4 individuals were collected from Georges Bank in June 1994. Error bars show \pm 1 SD. The 3 field populations of C5 C. finmarchicus were significantly different (1-way ANOVA and Duncan Multiple Range test, $p<0.05$ ). No statistical comparisons were made between laboratory cultures and field populations

lyzed by the 2 assays. The linear relationship used to convert the data was

$$
\begin{aligned}
\text { RNA:DNA }_{\text {MFA }} & =1.333\left(\text { RNA:DNA }_{\text {FIA }}\right)-0.0733, \\
& n=11, \mathrm{r}^{2}=0.981
\end{aligned}
$$

C5 Calanus finmarchicus from the Gulf of Maine had very different RNA:DNA ratios depending on the season in which they were collected (Fig. 4). The mean RNA:DNA ratio for animals collected in November 1993 over Wilkinson Basin and Jordan Basin was 0.74, while the mean for Georges Basin in June 1994 was 2.03. The mean RNA:DNA ratio for C5 C. finmarchicus from Georges Bank at the same time was 2.76. The 3 groups were significantly different (1-way ANOVA followed by Duncan Multiple Range test, $\mathrm{p}<0.05$ ).

\section{DISCUSSION}

Our data for length-at-stage agree with those of previous studies finding a positive relationship between food concentration and body size in other Calanus species (Mullin \& Brooks 1970, Frost 1974, Paffenhöfer 1976, Vidal 1980). Size-at-stage, although simple to measure, is not an adequate condition indicator since the body size of copepods can also be affected by temperature, especially in the older stages (Deevey 1960, McLaren 1965, Mullin \& Brooks 1970). Body size of some copepod species may also be influenced by genetic or parental factors, although these effects are small relative to those of the environment (McLaren 1976, McLaren \& Corkett 1978, Klein Breteler 1990). Because of the many factors influencing it, body size may be useful for comparing populations with similar temperature histories, but it cannot be used to infer recent feeding history, metabolic activity, or growth.

Calanus finmarchicus in this experiment showed a marked difference between the mean total DNA content of copepods in the 2 treatments (Fig. 3B). The well-fed animals had, depending on stage, from $15 \%$ to $50 \%$ more DNA per individual than copepods in the food-limited treatment. In vertebrates, total DNA content is considered to represent the number of cells in the organism, regardless of growth rate or condition (Bulow 1987). That is, all cells should contain roughly the same amount of DNA, so variations in DNA content should reflect changes in the number of cells. If the amount of DNA per cell is in fact constant, then the differences in total DNA content observed between the food treatments in this experiment suggest that cell number is higher at each stage for well-fed as compared to food-limited $C$. finmarchicus. There is some evidence that in Calanus and related copepods the total number of nuclei is the same among individuals at any given point in development (McLaren \& Marcogliese 1983). If cell number in C. finmarchicus is determinate, then the differences in total DNA observed between the food treatments would indicate differences in the amount of DNA per cell rather than the total number of cells per animal, possibly reflecting different rates of cell division and cell growth in the 2 treatments. More study of the relationship among body size, cell number, and DNA content is needed in order to reconcile the difference in DNA content of copepods in the 2 treatments.

Although the concentration of DNA itself can vary with age and condition. DNA content appears to be an acceptable way of normalizing RNA content in copepodite stages of this species. Since the 2 treatments in this experiment exhibited dramatic differences in RNA:DNA ratios over the range of stages studied (Fig. 3D), we conclude that the RNA:DNA ratio is an acceptable indicator of nutritional condition for $C$. finmarchicus. For Stages C1 to C4, there was little or no overlap between RNA:DNA frequency distributions for the 2 treatments (data not shown), indicating that it may be possible to infer the nutritional condition of an individual animal given its RNA:DNA ratio and stage.

Comparing data from the laboratory with data from the Gulf of Maine and Georges Bank (Fig. 4) demonstrates that RNA:DNA ratios are useful in monitoring the physiological condition of zooplankton in the field. Based on the time of year and the location of the animals deep in the water column, we expected that the C5 Calanus finmarchicus collected in the Gulf of Maine (Wilkinson Basin and Jordan Basin) in November 1993 would be in a resting stage. Live animals from these samples were brought to the laboratory and did 
not feed for more than a week despite the presence of excess phytoplankton in the cultures, confirming that these populations had low levels of physiological activity. RNA:DNA ratios of the C5 C. finmarchicus collected in the field were extremely low, even lower than those of the same stage in the food-limited laboratory cultures. Low RNA:DNA ratios are consistent with our expectation that these animals were in diapause. Stage C5 C. finmarchicus collected from the Gulf of Maine (Georges Basin) and from Georges Bank in May and June 1994 were expected to be active, again based on the time of year and also because they were located near the surface. RNA:DNA ratios of these animals were intermediate between the 2 laboratory food levels, consistent with food densities somewhere between the 2 extremes used in the experiment. C4 individuals from Georges Bank, like C5s from the same area, were also intermediate between the lab high- and low-food treatments. Although the laboratory and field populations could only be compared qualitatively since they were processed by different analytical techniques, the RNA:DNA ratios of $C$. finmarchicus copepodites in the Georges Bank-Gulf of Maine system follow a seasonal pattern that may be related to food availability or the reduced metabolic activity of diapause, or both.

The variation in RNA:DNA ratios observed in this study reflects the radical changes in growth and metabolic activity over the annual cycle and demonstrates that RNA:DNA ratios can be used as an indicator of nutritional status, and diapause, for Calanus finmarchicus and related species. Our future work will focus on quantifying the relationship between RNA. temperature, and growth rates and on monitoring the seasonal pattern of RNA and growth in greater detail.

Acknowledgements. This research was sponsored by National Science Foundation award OCE-9115818.

\section{LITERATURE CITED}

Båmstedt U (1983) RNA concentrations in zooplankton: seasonal variation in boreal species. Mar Ecol Prog Ser 11. 291-297

Båmstedt U, Skjoldal HR (1.976) Studies on the deep-water pelagic community of Korsfjorden, Western Norway adenosine phosphates and nucleic acids in Euchaeta norvegica (Copepoda) in relation to its life cycle. Sarsia 60: $63-80$

Båmstedt U, Skjoldal HR (1980) RNA concentration of zooplankton: relationship with size and growth. Limnol Oceanogr 25:304-316

Bentle LA, Dutta S, Metcoff J (1981) The sequential enzymatic determination of DNA and RNA. Anal Biochem 116 : $5-16$

Buckley LJ (1984) RNA-DNA ratio: an index of larval fish growth in the sea. Mar Biol 80:291-298

Bulow FJ (1987) RNA-DNA ratios as indicators of growth in fish: a review. In: Summerfelt $\mathrm{RC}$, Hall GC (eds) The age and growth of fish. The lowa State University Press, Ames
Caldarone E, Buckley LJ (1991) Quantitation of DNA and RNA in crude tissue extracts by flow injection analysis. Anal Biochem 100:188-197

Checkley DM Jr (1980) Food limitation of egg production by a marine, planktonic copepod in the sea off southern Califormia. Limnol Oceanogr 25:991-998

Clemmesen CM (1988) A RNA and DNA fluorescence technique to evaluate the nutritional condition of individual marine fish larvae. Meeresforschung 32:139-143

Dagg MJ, Littlepage JL (1972) Relationships between growth rate and RNA, DNA, protein and dry weight in Artemia salina and Euchaeta elongata. Mar Biol 17:162-170

Deevey GB (1960) Relative effects of temperature and food on seasonal variations in length of marine copepods in some eastern American and western European waters. Bull Bingham Oceanogr Collect Yale Univ 17:55-86

Durbin EG, Durbin AG, Smayda TJ, Verity PG (1983) Food limitation of production by adult Acartia tonsa in Narragansett Bay, Rhode Island. Limnol Oceanogr 28: $1199-1213$

Frost BW (1974) Feeding processes at lower trophic levels in pelagic communities. In: Miller $\mathrm{CB}$ (ed) The biology of the oceanic Pacific. Oregon State University Press, Corvallis, p $59-77$

Heinle DR (1966) Production of a calanoid copepod, Acartia tonsa, in the Patuxent river estuary. Chesapeake Sci 7 : $59-74$

Kimmerer WJ, Mackinnon AD (1987) Growth, mortality and secondary production of the copepod Arcatia tranteri in Westemport Bay, Australia. Limnol Oceanogr 32:14-28

Klein Breteler WCM, Schogt N, Gonzalez SR (1990) On the role of food quality in grazing and development of life stages, and genetic change of body size during cultivation of pelagic copepods. J Exp Mar Biol Ecol 135:177-189

McLaren IA (1965) Some relationships between temperature and egg size, body size, developmental rate, and fecundity of the copepod Pseudocalanus. Limnol Oceanogr 10 : $528-538$

McLaren IA (1976) Inheritance of demographic and production parameters in the marine copepod Eurytemora herdmani. Biol Bull (Woods Hole) 151:200-213.

McLaren IA, Corkett CJ (1.978) Unusual genetic variation in body size, development times, oil storage, and survivorship in the marine copepod Pseudocalanus. Biol Bull (Woods Hole) 155:347-359

McLaren IA, Marcogliese DJ (1983) Similar nucleus numbers among copepods. Can J Zool 61:721-724

Miller CB, Huntley ME, Brooks ER (1984) Post-collection molting rates of planktonic, marine copepods: measurement, applications, problems. Limnol Oceanogr 29: 1.274-1289

Mullin MM, Brooks ER (1970) Growth and metabolism of two planktonic, marine copepods as influenced by temperature and type of food. In: Steele JH (ed) Marine food chains. University of California Press, Berkeley, p 74-95

Nacci D, Cheer S, Jackim J, Juinio A (1994) Semiautomated fluorometric analysis of nucleic acids in tissue homogenates. Environ Toxicol Water Qual 9:123-130

Nakata K, Nakano H, Kikuchi H (1994) Relationship between egg productivity and RNA:DNA ratio in Paracalanus sp. in the frontal waters of the Kuroshio. Mar Biol 119:591-596

Ota AY, Landry MR (1984) Nucleic acids as growth rate indicators for early developmental stages of Calanus pacificus Brodsky. J Exp Mar Biol Ecol 80:147-160

Paffenhöfer GA (1976) Feeding, growth, and food conversion of the marine planktonic copepod Calanus helgolandicus. Limnol Oceanogr 21:39-50 
Runge JA (1985) Egg production of Calanus finmarchicus in the sea off Nova Scotia. Arch Hydrobiol Beih Ergebn Limnol 21:33-40

Runge JA, McLaren IA, Corkett CJ, Bohrer RN, Koslow JA (1985) Molting rates and cohort development of Calanus finmarchicus and $C$. glacialis in the sea off southwest Nova Scotia. Mar Biol 86:241-246

Skjoldal HR, Båmstedt U (1976) Studies on the deep-water pelagic community of Korsfjorden, Western Norway: adenosine phosphates and nucleic acids in Meganyctiphanes norvegica (Euphausiacea) in relation to the life

Editorial responsibility: Kenneth Sherman (Contributing Editor), Narragansett, Rhode Island, USA cycle. Sarsia 61:1-14

Sutcliffe WH Jr (1965) Growth estimates from ribonucleic acid content in some small organisms. Limnol Oceanogr 10 (Suppl): R253-R258

Sutcliffe WH Jr (1969) Relationship between growth rate and ribonucleic acid concentration in some invertebrates J Fish Res Board Can 27:606-609

Vidal J (1980) Physioecology of zooplankton. I. Effects of phytoplankton concentration, temperature, and body size on the growth rate of Calanus pacificus and Pseudocalanus sp. Mar Biol 56:111-134

Submitted: October 22, 1996; Accepted: July 10, 1997

Proofs received from author(s): February 4, 1998 